\title{
Is carpal tunnel release safe in electrical burn decompressive therapy: Six-years experience
}

\author{
Erdem Barış Cartı ${ }^{1}$ (D), Ahmet Deniz Uçar² (D), Mehmet Yıldırım²(D) \\ 1 Department of General Surgery, Adnan Menderes University Faculty of Medicine, Aydın, Turkey \\ ${ }^{2}$ Clinic of General Surgery, Health Sciences University Izmir Bozyaka Education and Research Hospital, Izmir, Turkey
}

\section{ABSTRACT}

Objective: Upper extremity electrical burn can create severe sequela and debilitation if not treated properly. Immediate decompression with fasciotomy and carpal tunnel release seem to be the most promising choice of treatment. Neurologic functional loss can be avoided if median nerve is liberated.

Material and Methods: During 6-year time interval, 50 out of 1158 burn patients underwent upper extremity decompressive fasciotomy with carpal tunnel release. Their hand motor function based on nerve innervation and daily usage questionnaire were followed in 12-month intervals.

Results: Average score rose markedly after $18^{\text {th }}$ month and reached nearly normal at the end of $66^{\text {th }}$ month. Median, ulnar and radial nerve function tests were all positive, and no irreversible nerve function loss observed.

Conclusion: All compartments of the forearm should be explored and carpal tunnel release should be added into upper extremity decompressive fasciotomy after electrical burns.

Keywords: Carpal tunnel, electric burn, burn

Cite this article as: Cartı EB, Uçar AD, Yıldırım M. Is carpal tunnel release safe in electrical burn decompressive therapy: Six-years experience. Turk J Surg 2021; 37 (2): 87-95

Corresponding Author Ahmet Deniz Uçar

E-mail: ahmetdenizucar@hotmail.com

Received: 25.11.2018

Accepted: 05.04.2020

Available Online Date: 30.06 .2021

() Copyright 2021 by Turkish Surgical Society Available online at www.turkjsurg.com

DOI: $10.47717 /$ turkjsurg.2021.4379

\section{INTRODUCTION}

After the first record of death in 1879, electrical injury has been one of the worst causative burn factors (1). It is reported that an average of 3000 admissions with a death rate of one over three are seen in the United States (2). Workplace is the most encountered area, being the fourth work-related death reason (3). Victims are generally in the productive age group, and upper extremity and/or hands are involved in more than $50 \%$ of cases $(3,4)$. Even both hands constitute not much than $3 \%$ total burned surface area (TBSA), it is accepted to be a major injury resulting dramatic disability.

Compartment syndrome after upper extremity burn can cause an additional damage to the extremities up to 72-hours (5). It was first described by Matsen as "critical increase of pressure in a limited space which restricts perfusion and viability of tissues in that space".

Even fasciotomy is performed in nearly all full thickness extremity burns, carpal tunnel release (CTR) seems to be less performed in clinical practice. Beside of the lack of sufficient number of prospective clinical trials investigating the pros and cons of adding CTR in decompressive fasciotomy, some studies have reported $37 \%$ insufficient decompression rates (6).

The reason to avoid carpal tunnel release can be the fear of damaging the median nerve. We tried to evaluate the effect of CTR on post-burn hand function assessment.

\section{MATERIAL and METHODS}

During the time interval between May 2011 and 2016, there were 1158 moderate or severe burn patients hospitalized in İmir Bozyaka Education and Research Hospital Burn Treatment Center. Three forearm compartments and CTR are routine surgical procedures in our center after upper extremity full thickness electrical burns. 
Decompressive surgery decision is always made by clinical findings of five "P's" and/or surgeons feeling without instrument using. These five "P's" of pain, pallor, paresthesia, paresis, and pulselessness are classical findings associated with elevated compartment pressure. We do not use instrumental methods such as intra-compartmental pressure monitoring, peripheral perfusion index et cetera.

Surgical anatomy and technique: Muscle component of different compartments is the primary target of the pathological process; where the nerves are the secondary targets. Following sustained vascular compromise, the muscle undergoes necrosis, fibrosis, and contracture. Associated nerve injury causes further muscle dysfunction, sensory deficits, or chronic pain. The result is a dysfunctional muscle compartment with local and distant manifestations.

The three forearm compartments are the flexor compartment which includes the finger; thumb, and wrist flexors, the lateral compartment containing the mobile wad of Henry which is represented by brachioradialis, extensor carpi radialis longus and brevis, and the extensor compartment containing finger, thumb extensors, and extensor carpi ulnaris.

The carpal tunnel is not a true compartment but may act as a closed space, and the median nerve may be subjected to the negative effects of increased pressure in case of which transverse carpal ligament should be released with exploration of the nerve in proximal forearm.

An S shaped incision starting from the antecubital region is finished in the palm center. Incision line should be kept in the burned skin area as much as possible (Figure 1). Incision crossing the joint region should not be straight. During upper limb fasciotomy, cutaneous nerve damage should be avoided while performing direct decompression of major nerves and/or ves- sels (Figure 2). Monopolar cautery should not be used since electrical currency tends to follow unfavorably in new, burned conditions, and cautery may give extra damage. Using scalpel for incisions and bipolar cautery for hemostasis is safer.

Functional outcome measurement after upper extremity decompressive surgery (UEDS) was performed with physical examination and questionnaire. We do not perform electromyography since it is an invasive method and can create medicolegal and ethical consequences. Physical exam of the hands was performed with the motor function tests of the muscle groups and corresponding nerve (Table 1). The questionnaire had 10 points giving chance to the patient comparing their hand function in daily and/or professional workup before and after the injury (and UEDS). The questions asked were nonspecific such as;

- How well did your hand(s) work from the last interview until now?

- How was the sensation (feeling) in your hand(s) from the last interview until now?

- How difficult was it for you to hold a hot object like a water filled glass during the last week?

- How difficult was it for you to dress up from the last interview until now?

- $\quad$ Describe the pain in your hand(s)/wrist(s) during the last six months?

- $\quad$ Are you satisfied with the appearance of your hand(s) and forearm(s)?

- Do you experience additional difficulty with the motion of your fingers and wrist?

Some specific conditions related to the patients' job or habits are additionally considered. Habitual fishing, frequent keyboard

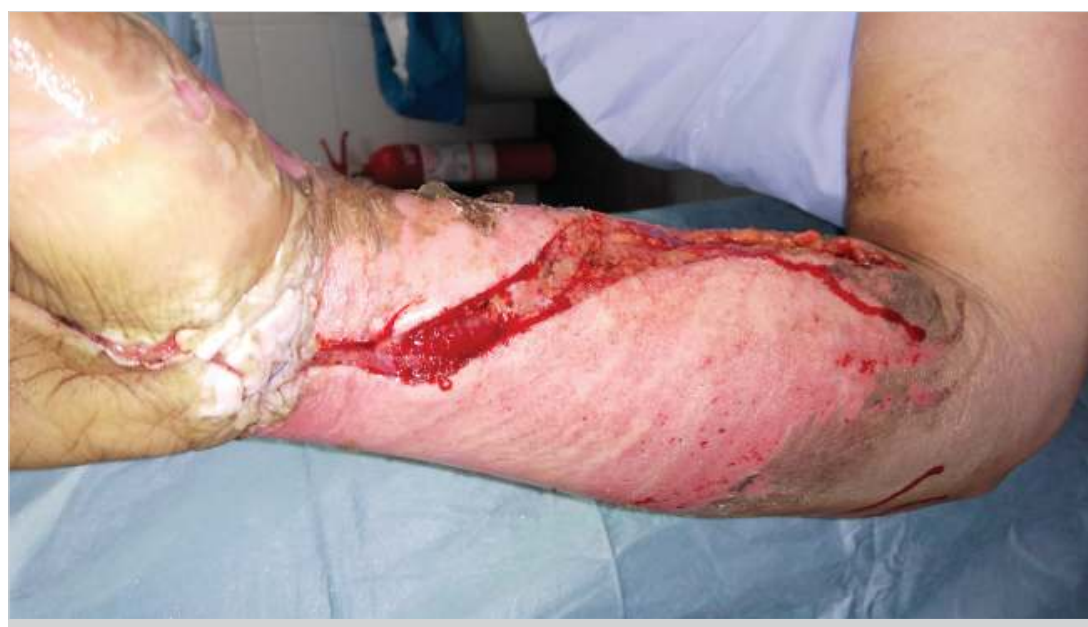

Figure 1. Secondarily healing of right forearm fasciotomy and carpal tunnel release operation. Note that fasciotomy line has been kept in burned area and tissue gap will probably be closed secondarily without grafting. 


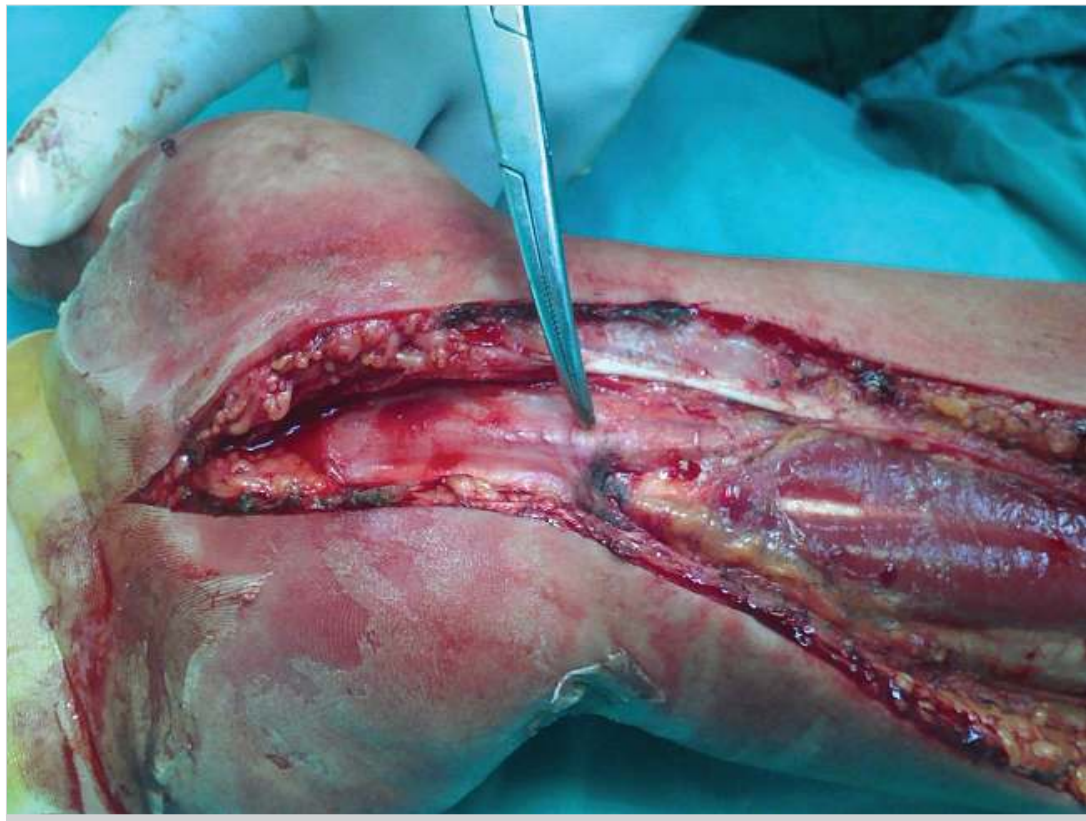

Figure 2. Isolation and liberation of median nerve shown at the tip of the clamp.

Table 1. Median and ulnar nerve motor function test chart

\begin{tabular}{|c|c|c|}
\hline Instruction to the patient & Checked muscle(s) & Innervated (checked) nerve \\
\hline Bend the tip of your thumb & Flexor Pollicis Longus & Median nerve \\
\hline $\begin{array}{l}\text { Bend the tip of your finger while stabilizing their PIP } \\
\text { joint }\end{array}$ & Flexor Digitorum Profundus & $\begin{array}{c}\text { Median nerve (radial half), Ulnar nerve } \\
\text { (ulnar half) }\end{array}$ \\
\hline $\begin{array}{l}\text { Bend your finger at the middle joint while stabilizing } \\
\text { their other fingers }\end{array}$ & Flexor Digitorum Superficialis & Median nerve \\
\hline Touch the thumb to the small finger & Thenar Muscles (radial group) & Recurrent branch of median nerve \\
\hline Spread your fingers apart & Interosseous Muscles & Deep branch of ulnar nerve \\
\hline $\begin{array}{l}\text { Grasp a piece of paper forcefully between the } \\
\text { thumb and radial side of the index proximal phalanx } \\
\text { (Froment's sign) }\end{array}$ & Adductor Pollicis & Deep branch of the ulnar nerve \\
\hline Bring your little finger away from the others & Hypothenar Muscles & Deep branch of ulnar nerve \\
\hline Bring your thumb out to the side & $\begin{array}{l}\text { Abductor Pollicis Longus } \\
\text { Extensor Pollicis Brevis }\end{array}$ & $\begin{array}{l}\text { Posterior interosseous branch of the } \\
\text { radial nerve }\end{array}$ \\
\hline $\begin{array}{l}\text { Lay your hand flat on a table and to "Lift only your } \\
\text { thumb off the table" }\end{array}$ & Extensor Pollicis Longus & $\begin{array}{l}\text { Posterior interosseous branch of the } \\
\text { radial nerve }\end{array}$ \\
\hline Straighten your fingers & Extensor Digitorum Communis & $\begin{array}{l}\text { Posterior interosseous branch of radial } \\
\text { nerve }\end{array}$ \\
\hline $\begin{array}{l}\text { Point with your index finger with the rest of your } \\
\text { hand in a fist }\end{array}$ & $\begin{array}{l}\text { Extensor Indicis Proprius } \\
\text { Extensor Digiti Minimi }\end{array}$ & $\begin{array}{l}\text { Posterior interosseous branch of radial } \\
\text { nerve }\end{array}$ \\
\hline \multirow{2}{*}{$\begin{array}{l}\text { Make a fist and strongly bring your wrist back" and } \\
\text { palpate over the tendons }\end{array}$} & Extensor Carpi Radialis Longus & Radial nerve \\
\hline & Extensor Carpi Radialis Brevis & Deep branch of radial nerve \\
\hline Pull your hand up and out to the side & Extensor Carpi Ulnaris & $\begin{array}{l}\text { Posterior interosseous branch of the } \\
\text { radial nerve }\end{array}$ \\
\hline
\end{tabular}


user, tailor, construction worker, farmer etc. are some examples for case specific additional question generation. After a 10 to 15 minutes of conversation, patients were asked to give a number between one (the worst) to 10 (the best-same before injury) for any limitation using their hands for daily living activities or professional works including fine works. If both hand UEDS was performed, worse hand function was accepted as reference arm. The points were recorded in six-month intervals. Every sixmonth interval groups were compared with themselves assuming that their preinjury scores were 10.

We did not obtain an ethical committee approval since this study is a retrospective observational study based on routine laboratory, imaging and physical examination findings which are mandatory during diagnosis, treatment and follow-up periods of the patients. Patients' (or his/her relatives when patient was unconscious) informed consents were obtained. This study was constricted under the considerations of Helsinki Declaration.

Statistical analysis was carried out by using Statistical Package for the Social Sciences version 22.0 (SPSS Inc., Chicago, IL, USA). Differences between groups or within groups were assessed by using Student t test for parametric data. p values less than 0.05 were accepted to be statistically significant.

\section{RESULTS}

During the six-year time interval between May 2011 and 2016, there were 1158 upper extremity burns. High voltage electric, as a causative factor, was found in 133 (11.4\%) patients. We recruited 78 patients that underwent UEDS procedure. Upper extremity contact point was detected, and decompressive surgery was performed in 67 (85.8\%) patients. Of them, there were 31 (46.2\%) patients having contact point at both hands. Contact point other than upper extremity were identified in 33 (24.8\%) patients. There were varying degrees of electric arc flame burns ranging between 2-44\% (TBSA) at different sites of the body, mainly the anterior trunk and extremities. Patients with mental problems, having previous upper extremity motor or sensation deficits, Mangled Extremity Severity Score more than eight, not willing to participate, coexisting severe trauma other than thermal or electrical burn, required death musculoskeletal tissue excision were exclusion criteria. Additional follow up resulted in 50 patients leaving the study subject pool. Mean age was 43.2 (14-67) years and female/male ratio was 5/45.

Time between injury to surgery was 14.6 (1-22) hours. Bilateral decompressive surgery was performed in 15 (30\%) patients. CTR and median nerve visualization and liberation are sine qua non for UEDS. We do not routinely open Guyon's channel. Loose retention sutures are put by using no:1 polypropylene sutures and further tightened after extremity swelling and tonus are reduced for primary closure preparation. By using this technique, 30 (60\%) needed no grafting procedure, and thus primary closure could be achieved. There was no reoperation for postoperative complication and/or additional decompression requirement. Extremity elevation, low molecular weight heparin prophylaxis, intravenous hydration based on urinary output were routine follow up protocol. Length of hospital stay in decompressive surgery patients was 32.4 (18-56) days. Median operation duration was 46 (22-255) minutes for only UEDS and additional procedure (fascial excision, grafting, amputations etc.). The only UEDS performed patient number was 17 (34\%).

Every patients' hand function status point (HFSP) was recorded by using a questionnaire we created (Table 2). We assumed

\begin{tabular}{|l|c|c|c|c|c|c|c|c|c|c|}
\hline \multirow{2}{*}{ Table 2. Hand function survey chart } \\
\hline
\end{tabular}


Table 3. Average scores of the questionnaires

\begin{tabular}{|l|c|c|c|}
\hline Groups & $\begin{array}{c}\text { Average score before injury } \\
\text { and UEDS (assumed to be) }\end{array}$ & $\begin{array}{c}\text { Average score after injury and } \\
\text { UEDS }\end{array}$ & N \\
\hline 72. month & 10 & 9.83 & NS \\
\hline 66. month & 10 & 9.77 & NS \\
\hline 60. month & 10 & 9.69 & NS \\
\hline 54. month & 10 & 9.56 & NS \\
\hline 48. month & 10 & 9.52 & NS \\
\hline 42. month & 10 & 9.48 & NS \\
\hline 36. month & 10 & 9.22 & NS \\
\hline 30. month & 10 & 9.38 & NS \\
\hline 24. month & 10 & 9.32 & NS \\
\hline 18. month & 10 & 9.25 & 0.04 \\
\hline 12. month & 10 & 7.68 & 0.03 \\
\hline 6. month & 10 & 6.52 & \\
\hline NS: Not significant. \\
UEDS: Upper extremity decompressive surgery.
\end{tabular}

that HFSP was 10 before injury and UEDS and every 6-month interval, average rescoring points were compared (Table 3 ). The average HFSP from the beginning of the UEDS was 6.52 and rise to 7.68 at the end of 12. month. After 18 months, HFSP reached to 9.25 and followed a plateau until 72. month (Figure 3). We found that HFSP before and after injury and UEDS was statistically significant at sixth and 12 . months $(p=0.03$ and $p=0.04)$, respectively. The percentage of patients' interpretation for not full recovery (points other than 10) were 100\% at the first sicth month but decreased to half after 18. month. After drawing a plateau until the 48. month, second drop was detected down to $17 \%$ (Table 2).

Motor function assessment of the median and ulnar nerve based on the muscle group movement instructions (Table 2) were detected in all patients. Secondary healing, graft healing, hand stiffness due to interosseous connective tissue damage may reduce the strength and range of motion of the muscle groups but movements in definitive extend could be visualized. This showed us that nerve innervation to every expected muscle of the hand was preserved after UEDS.

\section{DISCUSSION}

Upper extremities are prone to involve injury in more than 80\% of burn cases (7). Although both hands burn constitutes less than 3\% TBSA, their burn related sequela results very dramatic disabilities if not treated promptly (8).

Upper extremity nerve compression occurs in approximately $2 \%$ of the patients with severe burns (9). Patients with thermal burns greater than 20\% TBSA are also candidates for peripheral

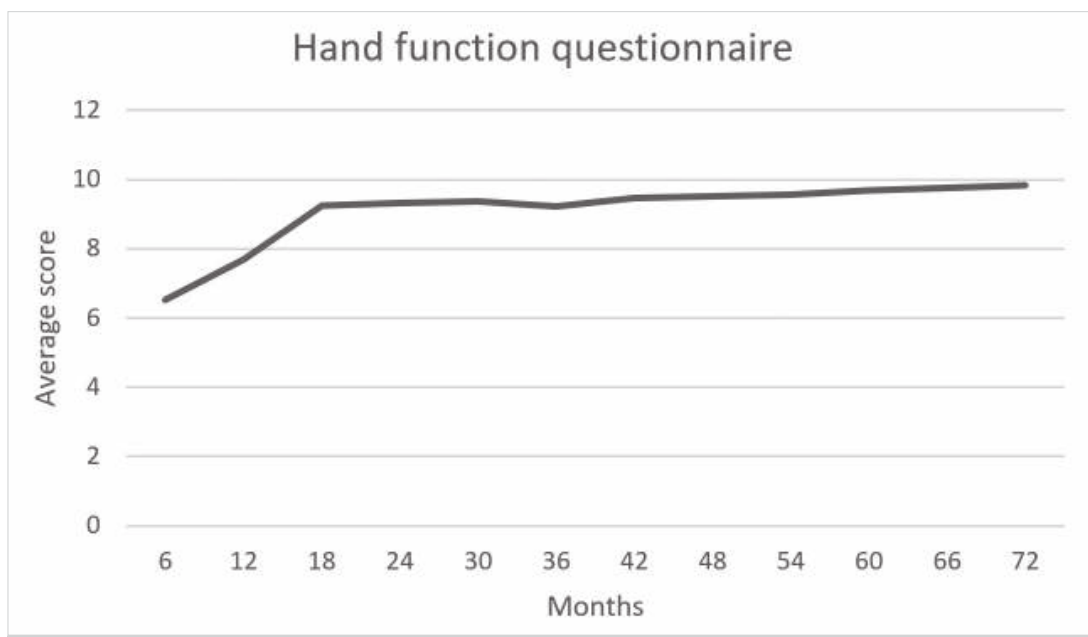

Figure 3. Average score progression during the 72 -month period. 
nerve compression in acute or long term follow up period (10). Sheridan et al. have demonstrated that $81 \%$ of the patients operated could have reached normal hand function when treated properly (11).

There is no clear data about the incidence of Carpal Tunnel Syndrome (CTS), and scarcity of the literature raises the question whether this is an uncommon problem or overlooked. Fortunately, some well documented large series exist and the incidence is $2-41 \%$ after electrodiagnostic work up $(9,10,12,13)$. Unfortunately, we did not perform any diagnostic tests to detect CTS so we cannot figure out the exact rate in our series.

Electrical and nonelectrical burns are quite different entities. Demographically, electrical burns mostly occur in the male population according to the literature, and low voltage $(<1000$ V) groups include more females and children whereas high voltage (>1000 V) group includes more male patients, which is relevant with our results. Upper extremity flame or scald burns effect the tissues from outside to inside in descending severity, whereas electrical burn excluding its arc burn, the most affected part is the core of the extremity. One can easily fall in a mistake by looking at the living, bleeding skin of the extremity while deep muscle and compartment ingredients have been heavily burned in fact (Figure 4). Hand wrists have disadvantageous anatomy where low resistant tissues are spared by high resistant tissues such as bone and tendons. Generation of high temperature from inside out fashion makes wrist region more than other body parts electric pass through. Skin is the main resistant organ to the electrical current. Wet, thin skin has low resistance and, in this case, internal tissues are much more effected than on the body with dry and thick skin coverage area. Five mechanisms of electrical burn damage are as follows: 1. Cell membrane resting potential alteration causing tetany of the muscles and tissue damage, 2. Conversion of electrical energy to thermal energy results coagulation necrosis, 3. Mechanical trauma due to contractions and/or falls (muscle rupture, bone fractures, internal organ damages), 4. The arc flame which has a temperature of $2500-10000^{\circ} \mathrm{C}, 5$. Blood flow obstruction resulting ischemic necrosis (14-16).

Normal intramuscular pressure ranges from 0 to $10 \mathrm{mmHg}$, and capillary perfusion threatens after pressure exceeds 30 $\mathrm{mmHg}$. Some authors suggest decompression for compartment pressures greater than $30 \mathrm{mmHg}$ (17-20) while some accepts $45 \mathrm{mmHg}$ as a critical threshold pressure, below which compartment syndromes were not observed (8). Since most of the heavily burned patients are hypotensive in acute period, a lower threshold of $30 \mathrm{mmHg}$ should be anticipated. Of course, there are several factors other than pressure elevation such as direct trauma, synovitis, wrist hyperextension, tight dress-

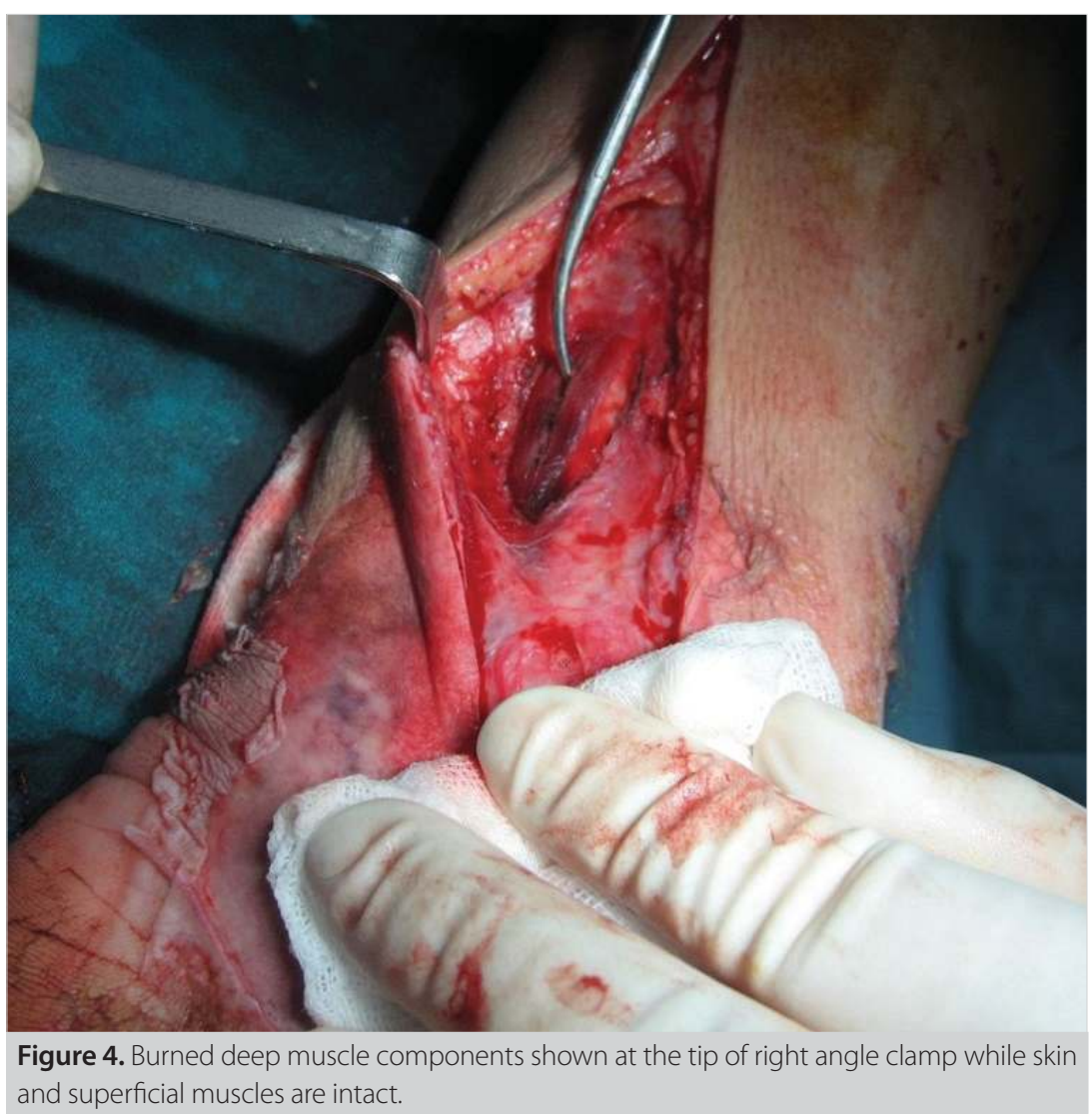


ing and fibrosis, vessel obstruction but duration of pressure elevation may be as important as the magnitude of pressure elevation (21-23). Muscle necrosis in a normotensive patient can occur after eight hours of exposure to pressures of only 30 $\mathrm{mmHg}$ (21) and pressure between 40 and $50 \mathrm{mmHg}$ presents a critical threshold beyond which nerve function is altered (24). The main symptoms are progressive onset of numbness in the median nerve distribution and pain in the fingers on passive extension in this case (25). Late onset nerve compression syndromes can be caused by the formation of scar tissue or heterotopic bone (26).

Phillips et al. have demonstrated that the earliest and most reliable indicator of increased compartment pressure is alteration in vibratory sensory testing using a 256-cps tuning fork in cooperative patients (27). There are several methods for compartment pressure prediction such as direct intramuscular monitoring, Xenon 133 scans, and et cetera, but these tests are not applicable neither for continuous monitoring nor multiple simultaneous screening.

After UEDS, a question rising how to evaluate hand function during follow up. Assessment methods such as Michigan Hand Outcomes Questionnaire (MHQ) and the Test d'Evaluation des Membres Supe'rieurs des Personnes Age'es (TEMPA) are not specifically designed for burned patients in which all the soft tissues and bony components are damaged in certain extend but instead, cover variety of patients including neuromuscular or rheumatologic disorders. They mainly deal with the range of motion and grip strength, but it is important to assess an individual's ability to use their hands in ordinary day life and profession for long follow up period. Patient generated scoring system seems to be more useful for burned patients since all the tissues in the hand and wrist regions are damaged at different levels. Functional categorization of the patients based on a performance is a good idea and challenged before (10). We, therefore, created a grading system of a 10-level scale for the patients for interpretation with the help of MHQ, TEMPA and Sheridan et al. (11,28-30). While checking motor functions of the median and ulnar nerves, we did not wait to see the precise and full power movements, instead motion or motor movements of corresponding muscle groups that were visible, sensible and sufficient to do patients' needs were accepted. Factors such as secondary healing, graft healing, hand stiffness due to the interosseous connective tissue damage may be the reason for poor or imprecise motor functions. What they should give importance during the tests and exact understanding of the questions were well understood by the patients since in hospital stay time was long enough for this.

We had no pre-burn values of the parameters, and test we studied in this trial and this will never be. Evaluation of success rate for the management of this kind of unexpected trauma will only have post-injury values. Patients may change their job, life style, habits and find some new ways to continue their daily life. This makes patients get accustomed to living in a new condition and forget their previous hand skills. Also, they may pretend to be normal, healthy, well skilled people as other unburned people and subconsciously give high points to the questionnaire. We always tried to make patients to remember their pre-burn life, skills and jobs while doing the survey.

Patient mental status after trauma and/or changing the interpretation criteria during late times are not studied in this study since we have no pre-burn mental examination, but most of the literature working on this showed no differences in mean score on mental functions between patients with burns and scores were found to be the similar with the healthy population (31).

If we accept that the points between 1-9 reflect the problems with daily life, marked improvement trends were observed during 12. to 18. months and after 60. months. This, however, differs with the study carried out by Xiao et al, in which they have observed $12-14 \%$ of patients mean TBSA (4\%) 15 weeks after discharge and in 3\% of patients (mean TBSA 69\%) at least two years after discharge (32). Their interpretation explains the relation between TBSA and daily life activity recovery rate in time.

The consensus of UEDS after electrical burn has been undisputable for a long time $(33,34)$. Beside escharotomy, electrical burns require other decompressive therapies such as fasciotomies or nerve releases with the recommendation level of $B$ (35). Neurological complication was the most common sequela (24). Peripheral neuropathy rates vary widely, from $2 \%$ to $84 \%$ (36-38). Since most of the electrical burns are work related and/ or has medicolegal consequences, malpractice considerations create a hesitation of including CTR to UEDS. Additional damage to the median nerve will never be differentiated from burn related functional loss, and this puts the burn surgeon under the spotlight of compensation procedures. Our study does not contain a control group, i.e., no carpal tunnel opened group. If there was, there might be no difference found. This speculation is supported with the ulnar nerve functional preservation in our series even we did not open the Guyon's canal routinely. However, it has been speculated that the release of the carpal tunnel will also reduce the Guyon's canal pressure, and release of Guyon's canal should not necessarily be done even ulnar nerve palsy is present (39). Likewise, decompression of the arm and forearm generally improves the digital perfusion, and digital escharotomy is not required in most of the cases (11).

\section{CONCLUSION}

Median and/or ulnar nerve palsy after electrical injury is uncommon but devastating. Whether or not the carpal tunnel and Guyon's canal be released during UEDS is not answered 
clearly in the literature $(33,40)$. In clinical practice, these injuries are mostly work related and be a subject for medicolegal and compensation circumstances. Although the beneficial effect of such decompression has not been proven up to now, most surgeons would continue to decompress the carpal tunnel. Otherwise, median or ulnar nerve palsies will be considered a sequela of incomplete, insufficient surgery i.e. leaving the nerves under compression and irreversible functional loss of the hand On the other hand, liberation of the median nerve may cause inadvertent surgical damage. It will never be differentiated that nerve malfunction is whether from the injury or a malpractice at all. Since patient homogenization is difficult due to the diverse varieties of the patients and ethical issues of having informed consent from the patient at poor cooperation in early time of injury, a randomized study will probably not be possible (41) Our study has shown that performing CTR in UEDS is safe and leads no neurological palsies in expert hands providing that there is no acute and marked tissue (bone, muscle, tendon etc.) loss at the forearm, wrist and hand.

Ethics Committee Approval: The approval for this study was obtained from Izmir Bozyaka Education and Research Hospital Clinical Research Ethics Committee (Decision No: 4, Date: 18.08.2015).

Peer-review: Externally peer-reviewed.

Author Contributions: Concept - E.B.Ç., A.D.U., M.Y.; Design - E.B.Ç., A.D.U., M.Y.; Supervision - E.B.Ç., A.D.U., M.Y.; Materials - E.B.Ç., A.D.U., M.Y.; Data Collection and/or Processing - E.B.C.., A.D.U., M.Y.; Analysis and/or Interpratation - E.B.C.., A.D.U., M.Y.; Literature Review - E.B.Ç., A.D.U., M.Y.; Writing Manuscript - E.B.Ç., A.D.U., M.Y.; Critical Reviews - E.B.Ç., A.D.U., M.Y.

Conflict of Interest: The authors declare that they have no conflict of interest.

Financial Disclosure: The authors declared that this study has received no financial support.

\section{REFERENCES}

1. Lee RC. Injury by electrical forces: pathophysiology, manifestation, and management. Curr Prob Surg 1997; 34(9): 684-5. [CrossRef]

2. Jain S, Bandi V. Electrical and lightning injuries. Crit Care Clin 1999; 15(2): 319. [CrossRef]

3. Helm PA. Burn rehabilitation: dimensions of the problem. Clinic Plast Surg 1992; 19(3): 551-9. [CrossRef]

4. Tredget E. Management of the acutely burned upper extremity. Hand Clin 2000; 16(2): 187-202. [CrossRef]

5. Allen MJ, Stirling AJ, Crawshaw CV, Barnes MR. Intracompartmental pressure monitoring of leg injuries. An aid to management. J Bone Joint Surg Br 1985; 67(1): 53-7. [CrossRef]

6. Burd A, Chiu T, Wong PS, Ng FY, Wong DS. The process of decompression in acute burns. Burns 2011; 37(4): 721. [CrossRef]

7. Kamolz LP, Kitzinger HB, Karle B, Frey M. The treatment of hand burns. Burns 2009; 35(3): 327-37. [CrossRef]
8. Wu C, Calvert CT, Cairns BA, Hultman CS. Lower extremity nerve decompression in burn patients. Ann Plast Surg 2013; 70(5): 563-7. [CrossRef]

9. Evans EB. Heterotopic bone formation in thermal burns. Clinical Orthop 1991;263: 94-101. [CrossRef]

10. Ferguson JS, Franco J, Pollack J, Rumbolo P, Smock M. Compression neuropathy: a late finding in the postburn population: a four-year institutional review. J Burn Care Res 2010; 31(3):458-61. [CrossRef]

11. Sheridan RL, Hurley J, Smith MA, Ryan CM, Bondoc CC, Quinby Jr WC, et al. The acutely burned hand: management and outcome based on a ten-year experience with 1047 acute hand burns. J Trauma 1995, 38(3): 406-11. [CrossRef]

12. Henderson B, Koepke GH, Feller I. Peripheral polyneuropathy among patients with burns. Arch Phys Med Rehabil 1971; 52(4): 149-51. [CrossRef]

13. Kowalske K, Holavanahalli R, Helm P. Neuropathy after burn injury. J Burn Care Rehabil 2001;22(5): 353-7. [CrossRef]

14. Dega S, Gnaneswar SG, Rao PR, Ramani P, Krishna DM. Electrical burn injuries. Some unusual clinic and management. Burns 2007; 33(5): 653-65. [CrossRef]

15. Lee RC, Zhang D, Hanning J. Biophysical injury mechanisms in electrical shock trauma. Annu Rev Bior Eng 2000; 2: 477-509. [CrossRef]

16. Martinez JA, Nguyen T. Electrical injuries. South Med J 2000; 93(12): 1165-8. [CrossRef]

17. Whitesides TE Jr, Haney TC, Morimoto K, Harada H. Tissue pressure measurements as a determinant for the need of fasciotomy. Clin Orthop 1975; 113: 43-51. [CrossRef]

18. Hargens AR, Schmidt DA, Evans KL, Gonsalves MR, Cologne JB, Garfin $S R$, et al. Quantitation of skeletal-muscle necrosis in a model compartment syndrome. J Bone Joint Surg Am 1981; 63(4): 631-6. [CrossRef]

19. Mubarak SJ, Hargens AR. Acute compartment syndromes. Surg Clin North Am 1983; 63(3): 539-65. [CrossRef]

20. Rorabeck CH. The treatment of compartment syndromes of the leg. $J$ Bone Joint Surg Br 1984; 66(1): 93-7. [CrossRef]

21. Hargens AR, Romine JS, Sipe JC, Evans KL, Mubarak SJ, Akeson WH. Peripheral nerve-conduction block by high muscle-compartment pressure. J Bone Joint Surg Am 1979; 61 (2): 192-200. [CrossRef]

22. Sheridan GW, Matsen FA 3rd, Krugmire RB Jr. Further investigations on the pathophysiology of the compartmental syndrome. Clin Orthop Relat Res 1977; 123:2 66-70. [CrossRef]

23. Rorabeck CH, Clarke KM. The pathophysiology of the anterior tibial compartment syndrome: an experimental investigation. J Trauma 1978; 18(5): 299-304. [CrossRef]

24. Gelberman RH, Szabo RM, Williamson RV, Hargens AR, Yaru NC, Minteer-Convery MA. Tissue pressure threshold for peripheral nerve viability. Clin Orthop 1983; 178: 285-91. [CrossRef]

25. Balakrishnan C, Mussman JL, Balakrishnan A, Khalil AJ. Acute carpal tunnel syndrome from burns of the hand and wrist. Can J Plast Surg 2009; 17(4): e33-4. [CrossRef]

26. Bossche LV, Vanderstraeten G. Heterotopic ossification: a review. J Rehabil Med 2005; 37(3): 129-36. [CrossRef]

27. Phillips JH, Mackinnon SE, Beatty SE, Dellon A, Lee MD, O'Brien JP. Vibratory sensory testing in acute compartment syndromes: A clinical and experimental study. Plast Reconstr Surg 1987; 79(5): 796. [CrossRef] 
If Ugland OM. A long-term psychosocial follow-up study of burned adults. Acta Psychiatr Scand Suppl 1989; 355: 94-102. [CrossRef]

29. Chung KC, Hamil JB, Walters MR, Hayward RA. The Michigan Hand Outcomes Questionnaire (MHQ): assessment of responsiveness to clinical change. Ann Plast Surg 1999; 42(6): 619-22. [CrossRef]

30. Desrosiers J, Hebert R, Dutil E. TEMPA Administration Manual. Hôpital d'Youville. Centre de recherche en gérontologie et gériatrie. d'Youville affilie' a I'Universitie' de Sherbrooke. Sherbrook, Quebec: 1991 [CrossRef]

31. van Baar ME, Essink-Bot ML, Oen IM, Dokter J, Boxma H, van Beeck EF. Functional outcome after burns: a review. Burns 2006; 32(1): 1-9. [CrossRef]

32. Xiao J, Cai BR. Functional and occupational outcome in patients surviving massive burns. Burns 1995; 21(6): 415-21. [CrossRef]

33. Kalyani BS, Fisher BE, Roberts CS, Giannoudis PV. Compartment syndrome of the forearm: a systematic review. J Hand Surg Am 2011; 36(3): 535-43. [CrossRef]

34. d'Amato TA, Kaplan IB, Britt LD. High-voltage electrical injury: a role for mandatory exploration of deep muscle compartments. J Nat/ Med Assoc 1994; 86(7): 535-7. [CrossRef]
35. Orgill DP, Piccolo N. Escharotomy and decompressive therapies in burns. J Burn Care Res 2009; 30(5): 759-68. [CrossRef]

36. Helm PA, Pandian G, Heck E. Neuromuscular problems in the burn patient: cause and prevention. Arch Phys Med Rehabil 1985; 66(7): 451-3. [CrossRef]

37. Monafo WW, Eliasson SG. Sciatic nerve function following hindlimb thermal injury. J Surg Res 1987; 43(4):344-50. [CrossRef]

38. Marquez S, Turley JJ, Peters WJ. Neuropathy in burn patients. Brain 1993; 116(Pt 2): 471-83. [CrossRef]

39. Geary N. Late surgical decompression for compartment syndrome of the forearm. J Bone Joint Surg 1984; 66(5): 745-8. [CrossRef]

40. Grottkau BE, Epps HR, Di Scala C. Compartment syndrome in children and adolescents. J Pediatr Surg 2005; 40: 678-82. [CrossRef]

41. Kline SC, Moore JR. Neonatal compartment syndrome. J Hand Surg 1992; 17(2): 256-9. [CrossRef]

\section{ORIJINAL ÇALIŞMA-ÖZET}

Turk J Surg 2021; 37 (2): 87-95

\section{Elektrik yanıkları sonrası karpal tünel açılması güvenli midir? Altı yıllık deneyim}

\section{Erdem Barış Cartı ${ }^{1}$, Ahmet Deniz Uçar ${ }^{2}$, Mehmet Yıldırım²}

${ }^{1}$ Adnan Menderes Üniversitesi Tıp Fakültesi, Genel Cerrahi Anabilim Dalı, Aydın, Türkiye

${ }^{2}$ Sağlık Bilimleri Üniversitesi İzmir Bozyaka Eğitim ve Araştırma Hastanesi, Genel Cerrahi Kliniği, İzmir, Türkiye

\section{ÖZET}

Giriş ve Amaç: Üst ekstremite elektrik yanıkları, uygun şekilde tedavi edilmezse şiddetli sekel ve fonksiyon kaybı yaratabilir. Fasiyotomi ve karpal tünel açılması ile derhal dekompresyon, en umut verici tedavi seçeneği olarak görünmektedir. Median sinir serbestleştirilir ise, nörolojik fonksiyonel kayıptan kaçınılabilir.

Gereç ve Yöntem: Altı yıl arayla toplam 1158 yanık hastasının 50'sinde üst ekstremite dekompresif fasiyotomi ve karpal tünel serbestleştirilmesi yapıldı. Sinir innervasyonuna dayanan el motor fonksiyonu ve günlük el kullanım anketi 12 aylık aralıklarla takip edildi.

Bulgular: Ortalama skor 18. aydan sonra belirgin bir şekilde yükseldi ve 66. ayın sonunda normal seviyeye ulaştı. Median, ulnar ve radial sinir fonksiyon testi pozitifti ve geri dönüşü olmayan sinir fonksiyon kaybı gözlenmedi.

Sonuç: Ön kolun tüm bölümleri araştııılmalı ve elektrik yanıklarından sonra üst ekstremite dekompresif fasiyotomiye karpal tünel serbestleştirilmesi eklenmelidir.

Anahtar Kelimeler: Karpal tünel, elektrik yanığı, yanık

Doi: 10.47717/turkjsurg.2021.4379 